\title{
Analysis of the Blood Type and Group among Undergraduate Physics Students of Dilla University, Ethiopia
}

Atire FA*

Department of Biology, College of Natural and Computational Sciences, Dilla University, Dilla, Ethiopia

*Corresponding author: Fekadu Alemu Atire, Department of Biology, College of Natural and Computational Sciences, Dilla University, Dilla, Ethiopia, Tel: 25-192-0839215; E-mail: fekealex@gmail.com

Rec date: December 2, 2014, Acc date: January 23, 2015, Pub date: January 26, 2015

Copyright: ( 2015 Atire FA. This is an open-access article distributed under the terms of the Creative Commons Attribution License, which permits unrestricted use, distribution, and reproduction in any medium, provided the original author and source are credited.

\begin{abstract}
The plasma membrane of a mature red blood cell has glycol-proteins and glycol-lipids that determine a person's blood type. Blood types $\mathrm{A}, \mathrm{B}, \mathrm{AB}$, and $\mathrm{O}$ form the $\mathrm{ABO}$ blood group. $\mathrm{ABO}$ blood type is determined by the hereditary presence or absence of antigens $A$ and $B$ on Red Blood Cells. Blood types and transfusion compatibility are $a$ matter of interactions between plasma proteins and erythrocytes. A blood sample was taken from the voluntary Physics students of Dilla University. Blood type (groups) varies among each ethnic group, A, B, AB and O blood groups were analysis for these ethnic group of Physics department students found in Dilla University, Amhara state, Oromia state, South Nation Nationalities People, Tigray state and Gembella people. The distribution of blood group $O$ was the highest with percentage frequency of $38.33,29.44$ and $28.88 \%$, followed by blood group $A$ and blood group $B$, and the least percentage frequency is that of blood group $A B$ with $3.33 \%$ among each ethnic groups. The highest Rh-blood types were $91.66 \%$ Rh-positive blood types followed by $8.34 \%$ Rh-negative blood types. Therefore, among each ethnic groups of Ethiopian students, the blood type and groups were varies in all voluntary students of Dilla University.
\end{abstract}

Keywords: Blood groups; Blood type; Dilla University; Rh-factors; Voluntary students

\section{Introduction}

Ethiopia is divided into nine kilil (states) and two astedader (administrations). Addis Ababa (3,147,000), Afar (1,449,000), Amhara $(20,136,000)$, Benshangul-Gumaz $(656,000)$, Dire Dawa $(428,000)$, Gambela Peoples $(259,000)$, Harari People $(209,000)$, Oromia $(28,067,000)$, Somali $(4,560,000)$, Southern Nations, Nationalities and Peoples (SNNP) $(15,745,000)$ and Tigray $(4,565,000)$ and the total population of Ethiopia at 2007 was 79,221,000 [1]. Blood group antigens are hereditary determined and plays a vital role in transfusion safety, understanding genetics, inheritance pattern, and disease susceptibility. Nearly 700 erythrocyte antigens are described and organized into 30 blood group systems by the International Society of Blood Transfusion of which ABO and Rh are important [2].

All human populations share the same blood group systems; although they differ in the frequencies of specific types. The incidence of $\mathrm{ABO}$ and $\mathrm{Rh}$ groups varies markedly in different races, ethnic groups, and socio-economic groups in different part of the world [3]. The differences in human blood are due to the presence or absence of certain protein molecules called antigens and antibodies. The antigens are located on the surface of the red blood cells and the antibodies are in the blood plasma. Individuals have different types and combinations of these molecules [4]. According to ABO and Rh blood grouping systems, a person can belong to either of following 8 blood groups: A Rh+, A Rh-, B Rh+, B Rh-, AB Rh+, AB Rh-, O Rh+ and O Rh-. Our blood cells have a variety of chemicals on their surfaces called antigens. Blood cells from different people have different antigens (anti=against, opposite) on them, and which ones a person has depend on what genes that person has. External surface of RBC membrane is coated with a diverse array of glycol-proteins, complex carbohydrates, and lipoproteins, imparting antigenic structure to the membrane (Figure 1).

The blood grouping is done in laboratories by slide test which is a manual method. Most of the techniques applied are still based on the principle of interaction between antigen and antibody and subsequent agglutination of RBCs (positive result).The absence of agglutination indicates the lack of interaction (negative result) [5] (Figure 2).

$\mathrm{ABO}$ and $\mathrm{Rh}$ blood groups are the most important blood groups despite the long list of several other blood groups discovered so far $[6,7]$. The two significant blood group systems were discovered during early experiments with blood transfusions, the ABO group in 1901 and the rhesus group in 1939 [8]. Furthermore, the discovery of ABO and $\mathrm{Rh}$ blood groups has contributed immensely to blood banking services and transfusion medicine in order to avoid morbidity and mortality in both adults and children.

The $\mathrm{ABO}$ and $\mathrm{Rh}$ blood groups varies worldwide and are not found in equal numbers even among different ethnic groups. Among African-American ABO blood group, the distribution of type O, 46\%; type $A, 27 \%$; type $B, 20 \%$; and type $A B ; 7 \%$. In Caucasians in the United State, the distribution is type O, $47 \%$; type A, $41 \%$; type B, $9 \%$; type $\mathrm{AB}, 3 \%$. Also, among Western Europeans, type O, $46 \%$; type A, $42 \%$; type $B, 9 \%$; and type $A B, 3 \%[9,10]$. Moreover, Rh-positive is documented as $95 \%$ in African-Americans, $100 \%$ in Africans whereas Rh- negative is $5.5 \%$ in South India, $5 \%$ in Nairobi, $7.3 \%$ in Lahore, $4.8 \%$ in Nigeria [11,12].

Agglutination is the clumping of particles with antigens on their surface, such as erythrocytes by antibody molecules that form bridges between the antigenic determinants. When, antigens are situated on the red cell membrane, mixture with their specific antibodies causes clumping or agglutination of the red cells. The agglutination of red 
cells takes place in two stages. In the first stage- sensitization, antibodies present in the serum become attached to the corresponding antigen on the red cell surface.

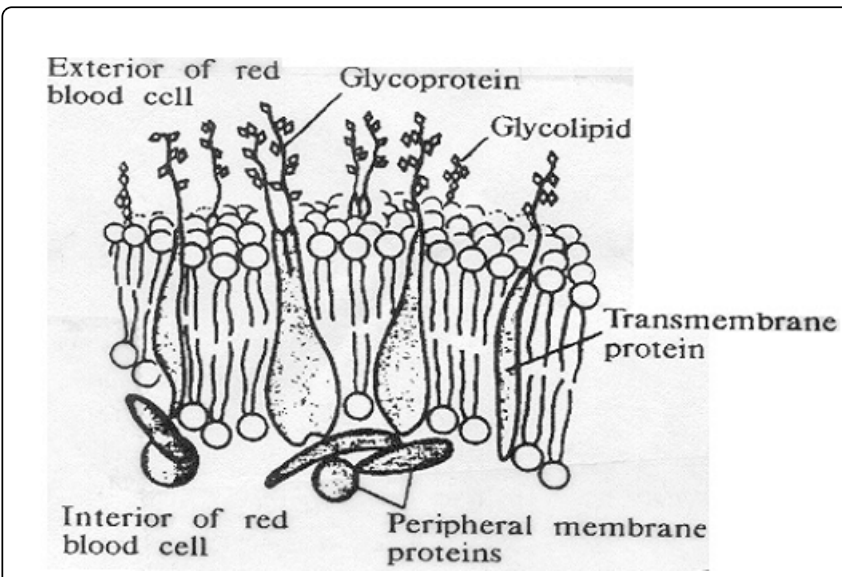

Figure 1: Red blood cell membrane

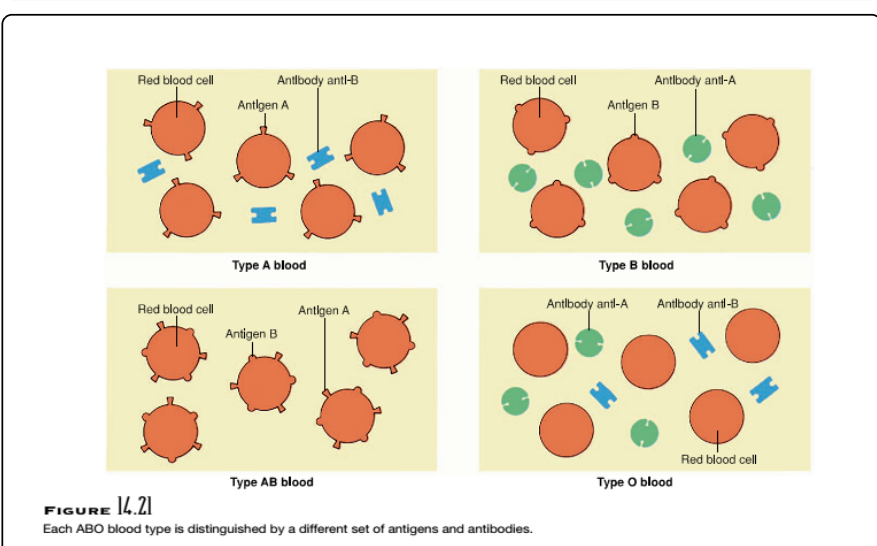

Figure 2: Each $\mathrm{ABO}$ blood type is distinguished by a different set of antigens and antibodies [5]

A red cell, which has thus coated by antibodies is said to be sensitized. In the second stage, the physical agglutination or clumping of the sensitized red cells takes place, which is caused by an antibody attaching to antigen on more than one red cell producing a net or lattice that holds the cells together. The cells form aggregates, which if large enough, are visible to the naked eye. There are also degrees of agglutination which cannot be seen without the aid of a microscope.

The $\mathrm{ABO}$ and $\mathrm{Rh}$ blood groups varies worldwide and are not found in equal numbers even among different ethnic groups. Among African-American $\mathrm{ABO}$ blood group, the distribution of type $\mathrm{O}, 46 \%$; type $A, 27 \%$; type $B, 20 \%$; and type $A B ; 7 \%$. In Caucasians in the United State, the distribution is type O, $47 \%$; type A, $41 \%$; type B, $9 \%$; type $\mathrm{AB}, 3 \%$. Also, among Western Europeans, type O, 46\%; type $\mathrm{A}$, $42 \%$; type $\mathrm{B}, 9 \%$; and type $\mathrm{AB}, 3 \%[9,10]$. Moreover, Rh-positive is documented as $95 \%$ in African-Americans, $100 \%$ in Africans whereas Rh- negative is $5.5 \%$ in South India, $5 \%$ in Nairobi, $7.3 \%$ in Lahore, $4.8 \%$ in Nigeria $[11,12]$.

Agglutination is the clumping of particles with antigens on their surface, such as erythrocytes by antibody molecules that form bridges between the antigenic determinants. When, antigens are situated on the red cell membrane, mixture with their specific antibodies causes clumping or agglutination of the red cells. The agglutination of red cells takes place in two stages. In the first stage- sensitization, antibodies present in the serum become attached to the corresponding antigen on the red cell surface. A red cell, which has thus coated by antibodies is said to be sensitized. In the second stage, the physical agglutination or clumping of the sensitized red cells takes place, which is caused by an antibody attaching to antigen on more than one red cell producing a net or lattice that holds the cells together. The cells form aggregates, which if large enough, are visible to the naked eye. There are also degrees of agglutination which cannot be seen without the aid of a microscope.

The knowledge of distribution of $\mathrm{ABO}$ and $\mathrm{Rh}$ blood groups at local and regional levels are helpful in the effective management of blood banks and safe blood transfusion services. Identification of Rh system is important to prevent the erythroblastosis fetalis; which commonly arises when an $\mathrm{Rh}$ negative mother carries an $\mathrm{Rh}$ positive fetus. Knowledge of the distribution of $\mathrm{ABO}$ and $\mathrm{Rh}$ blood group is essential for effective management of blood banks inventory, be it a facility of a smaller local transfusion service or a regional or national transfusion service. It is, therefore, imperative to have information on the distribution of these blood groups in any population [13].

Knowledge of blood group distribution is also important for clinical studies, for reliable geographical information and it will help a lot in reducing the maternal mortality rate, as access to safe and sufficient supply of blood will help significantly in reducing the preventable deaths.

Knowing their blood group help to minimize the risk factor during marriage such as erythroblastosis disease occurs after marriage and miss-donating blood to the patients or miss-receiving. This study is aimed to determine frequency and distribution $\mathrm{ABO}$ and $\mathrm{Rh}$ blood group patterns among Physics student found at Dilla University, Ethiopia.

\section{Materials and Methods}

\section{Study site and sample of population}

This study was carried out at the College of Natural and Computational Science, Department of Biology, in Microbiology Laboratory at Dilla University, Ethiopia, during 2014. A total of 180 voluntary students of Physics Department were randomly selected among the Dilla University students. The blood collections were taken from the voluntary Physics students of Dilla University. The students were divided into five major ethnic groups i.e., Amhara, Southern Nations Nationalities and Peoples (SNNP), Oromia, Gambela Peoples, Tigray and ethnic groups. Out of 180 voluntary students were 142 males and 38 females. All were of ages between 19-24 years.

\section{$\mathrm{ABO}$ and Rh-blood group's tests}

Blood samples from each student was taken by Scrub" with "scrubbing with a piece of cotton saturated with $70 \%$ alcohol and pierce it with a sterile disposable lancet and was placed a small drop of blood on a three clean white glass microscope slide on which a few drops of antisera for blood group A and B was applied (Figure 3). 
Citation: Atire FA (2015) Analysis of the Blood Type and Group among Undergraduate Physics Students of Dilla University, Ethiopia. Hereditary

Page 3 of 8

\section{Ethical clearance}

The study protocol was reviewed and approved by Dilla University ethical clearance committee. Before data collection, an informed consent was obtained from respondents.

\section{Date analysis}

Data on the frequency of $\mathrm{ABO}$ and $\mathrm{Rh}$ blood groups was reported in simple percentages and graphic.

\section{Results and Discussion}

Knowing $\mathrm{ABO}$ blood type and $\mathrm{Rh}$ blood group is the most important antigenic system in transfusion. Blood type (groups) varies among each ethnic group, $\mathrm{A}, \mathrm{B}, \mathrm{AB}$ and $\mathrm{O}$ blood groups were analysis for these ethnic group of Physics department students found in Dilla University, Amhara state, Oromia state, South Nation Nationalities People, Tigray state and Gembella people. The voluntary students of Physics, males and females were taken from Amhara state, 24.32\%,
$24.32 \% 2.70 \%, 35.14 \%$ and $5.41 \%, 5.41 \%$, O $\% 2.7 \%$ blood types A, B, $\mathrm{AB}$ and $\mathrm{O}$ were determined respectively. The voluntary students of Physics, males and females were taken from SNNP, 20.51\% , 25.64\% $2.56 \%, 20.51 \%$ and $5.13 \%, 10.25 \%, 0 \% 15.85 \%$ blood types $\mathrm{A}, \mathrm{B}, \mathrm{AB}$ and $\mathrm{O}$ were determined respectively.

The frequency of $\mathrm{ABO}$ blood groups varies from race to race. The country wise figure in Caucasians for the United States, the distribution is type $\mathrm{O}=47 \%$, type $\mathrm{A}=41 \%$, type $\mathrm{B}=9 \%$, and type $\mathrm{AB}=3 \%$. Among African American, the distribution is type $\mathrm{O}=46 \%$, type $A=27 \%$, type $B=20 \%$, and type $A B=7 \%$. Among Western Europeans, $42 \%$ population shows blood group A, $9 \%$ blood group B, $3 \%$ blood group $\mathrm{AB}$ and the remaining $46 \%$ blood group $\mathrm{O}[14,15]$. Many other studies have shown that blood group $\mathrm{O}$ was the most common blood group and blood group $\mathrm{AB}$ was the least common blood group in different ethnic groups [16]. For instance, in AfricanAmerican $\mathrm{ABO}$ blood group, the distribution of type $\mathrm{O}, 46 \%$; type $\mathrm{A}$, $27 \%$; type B, $20 \%$; and type AB; $7 \%$.
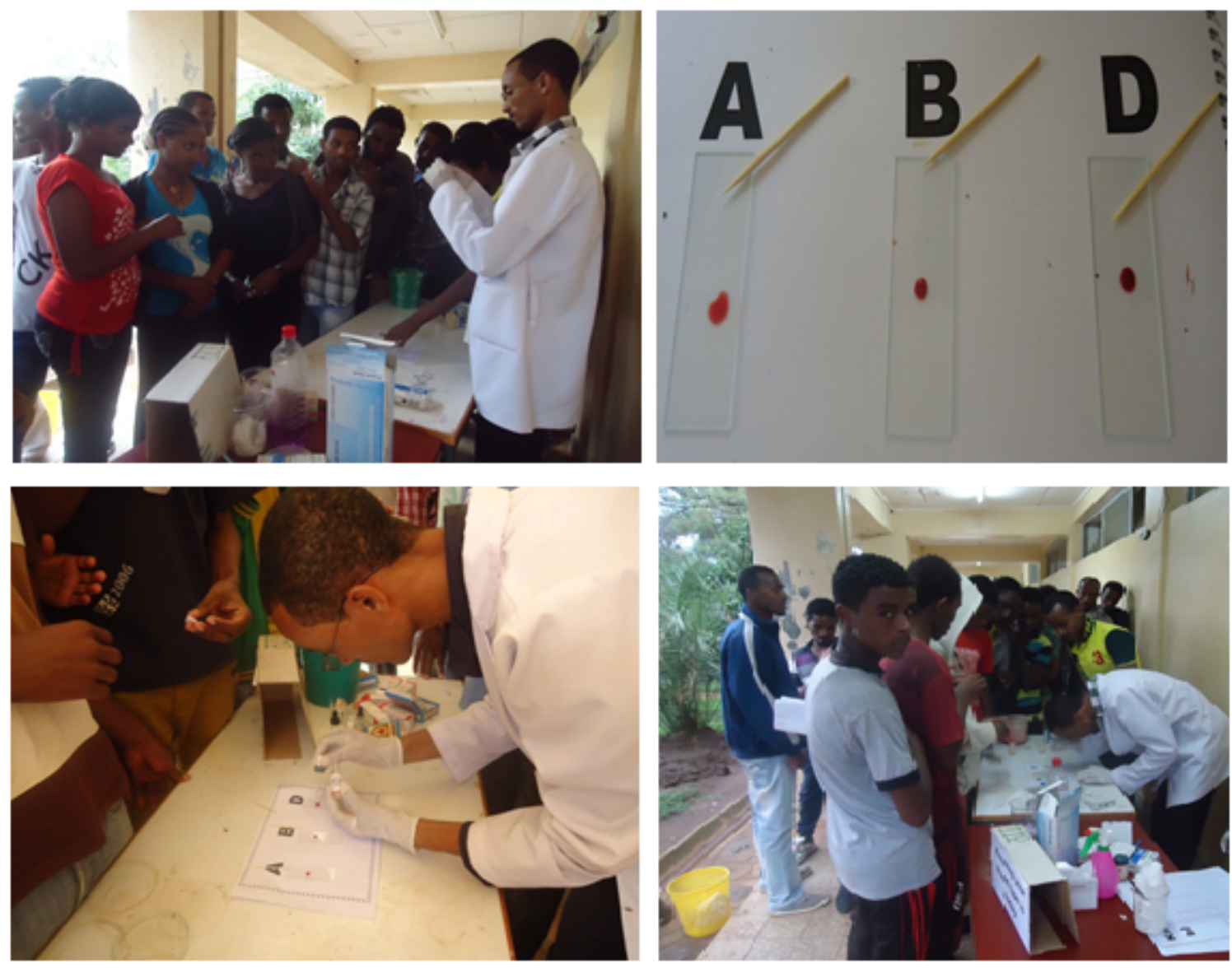

Figure 3: During blood sample collection from voluntary students of Physics at Dilla University ( $\mathrm{A}=$ during blood sample taken, $\mathrm{B}=$ placed of blood sample on clean libeled slide, $\mathrm{C}=$ addition of ant-bodies of on collected blood sample and $\mathrm{D}=$ observation of the result whether form agglutinates or remain fluid not agglutinates) 
Normally, the distribution of ABO blood groups varies from one population to another. In many other studies, blood group $\mathrm{O}$ has been found to be the most common blood group. In the Caucasians in the United States, the distribution is group O, $47 \%$, group A, $41 \%$, group B, $9 \%$ and group AB, 3\% [7]. Among Western Europeans 42\% are group $\mathrm{A}, 9 \%$ group $\mathrm{B}, 3 \%$ group $\mathrm{AB}$ and the remaining $46 \%$ group $\mathrm{O}$. For blacks in United States, the distribution is group $\mathrm{O}, 46 \%$, group A, $27 \%$, group $B, 2 \%$, and group $A B, 7 \%$ [7].

The voluntary students of Physics, males and females were taken from Oromia state, $23.07 \%, 13.46 \% 1.92 \%, 32.69 \%$ and $9.62 \%, 9.62 \%$, $3.85 \%, 5.77 \%$ blood types $\mathrm{A}, \mathrm{B}, \mathrm{AB}$ and $\mathrm{O}$ were determined respectively. The voluntary students of Physics, males and females were taken from Gambela Peoples, $20.00 \%, 40.00 \%, 0 \%, 40.00 \%$ and $0 \%, 0 \%, 0 \%, 0 \%$ blood types $\mathrm{A}, \mathrm{B}, \mathrm{AB}$ and $\mathrm{O}$ was determined respectively. The voluntary students of Physics, males and females were taken from Tigray, $30.00 \%, 20.00 \%, 0 \%, 40.00 \%$ and $0 \%, 0 \%, 0 \%$, $10.00 \%$ blood types $\mathrm{A}, \mathrm{B}, \mathrm{AB}$ and $\mathrm{O}$ were determined respectively (Table 1). In Caucasians in the United State, the distribution is type $\mathrm{O}$, $47 \%$; type A, $41 \%$; type B, $9 \%$; type $\mathrm{AB}, 3 \%$. Also, among Western Europeans, type O, $46 \%$; type $A, 42 \%$; type $B, 9 \%$; and type $A B, 3 \%$ $[9,10]$. Thus, the gene segregation for ABO systems always followed a particular pattern for its distribution in different ethnic group with exceptional cases.

\begin{tabular}{|l|l|l|l|l|l|l|}
\hline Ethnic Groups & Sex & A & B & AB & O & Total \\
\hline Amhara & Male & $18(24.32 \%)$ & $18(24.32 \%)$ & $2(2.70 \%)$ & $26(35.14 \%)$ & $64(86.49 \%)$ \\
& Female & $4(5.41 \%)$ & $4(5.41 \%)$ & - & $2(2.70 \%)$ & $10(13.51 \%)$ \\
\hline SNNP & Male & $8(20.51 \%)$ & $10(25.64 \%)$ & $1(2.56 \%)$ & $8(20.51 \%)$ & $27(69.23 \%)$ \\
& Female & $2(5.13 \%)$ & $4(10.25 \%)$ & - & $6(15.85 \%)$ & $12(30.77 \%)$ \\
\hline Oromia & Male & $12(23.07 \%)$ & $7(13.46 \%)$ & $1(1.92 \%)$ & $17(32.69 \%)$ & $37(71.15 \%)$ \\
& Female & $5(9.62 \%)$ & $5(9.62 \%)$ & $2(3.85 \%)$ & $3(5.77 \%)$ & $15(28.85 \%)$ \\
\hline Gambela Peoples & Male & $1(20.00 \%)$ & $2(40.00 \%)$ & - & $2(40.00 \%)$ & $5(100.00 \%)$ \\
& Female & - & - & - & - & - \\
\hline Tigray & Male & $3(30.00 \%)$ & $2(20.00 \%)$ & - & $4(40.00 \%)$ & $9(90.00 \%)$ \\
& Female & - & - & - & $1(10.00 \%)$ & $1(10.00 \%)$ \\
\hline Total & & $53(29.44 \%)$ & $52(28.88 \%)$ & $6(3.33 \%)$ & $69(38.33 \%)$ & \\
\hline
\end{tabular}

Table 1: ABO blood group distribution among ethnic groups of 180 Physics students of Dilla University, Ethiopia

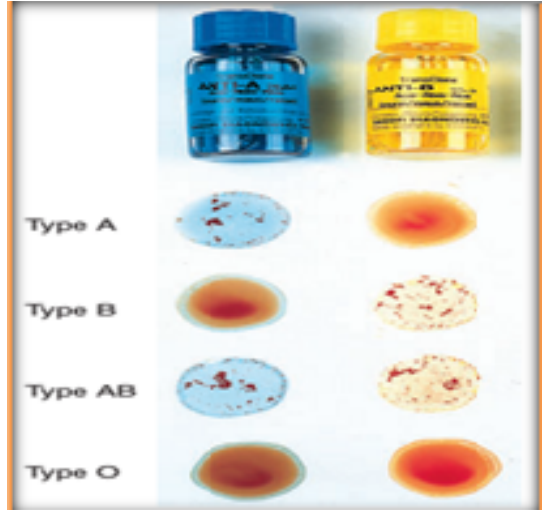

Figure 4: $\mathrm{ABO}$ Blood typing each row shows the appearance of a drop of blood mixed with anti-A and anti-B antisera. Blood cell becomes clumped if they possess the antigens for the antiserum (top row left, second row right third row both) but otherwise remain uniformly mixed. Thus type A agglutinates only in anti-A; type $\mathrm{B}$ agglutinates in anti- $\mathrm{B}$; type $\mathrm{AB}$ agglutinates in both and type $\mathrm{O}$ agglutinates in neither of them

A drop of each of the antisera, anti A, anti B and anti D were added and mixed with each blood sample, with the aid of wood toothpick. Blood was mixed thoroughly with the antisera and rocked gently for
$60 \mathrm{sec}$ to observe agglutination. In case of doubt, the test was examined under a microscope, or the results was confirmed by reverse grouping using known group A and B red cells [14] (Figure 4).

\section{Distribution of ABO blood types among physics students at Dilla University}

The distribution of $\mathrm{ABO}$ blood groups varies regionally, ethnically and from one population to another. As indicated in the (Figure 5), the frequency distribution of blood group $\mathrm{O}$ was the highest with percentage frequency of $38.33,29.44$ and $28.88 \%$, followed by blood group A and blood group B, and the least percentage frequency is that of blood group $\mathrm{AB}$ with $3.33 \%$ among each ethnic groups as observed in previous studies [16-18]. Similarly, Hussain [19] had reported at 2013 the distribution of blood group $O$ was the highest with percentage frequency of $29.97 \%$ followed by blood groupA $126.52 \%$, B $20.03 \%$, A1B $19.34 \%$, and A2 $2.90 \%$ and the least percentage frequency is that of blood group A2B which is $1.24 \%$. Also, it has been reported in several studies that there are variation in $\mathrm{ABO}$ blood group among different ethnic groups [16-18]. Patel [20] had reported that looking at the rhesus grouping, on female sex, $7.50 \%$ were $\mathrm{Rh}$ positive $\mathrm{AB}$ blood type and remaining $0.42 \%$ were $\mathrm{Rh}$ negative $\mathrm{AB}$ blood type. 
Page 5 of 8

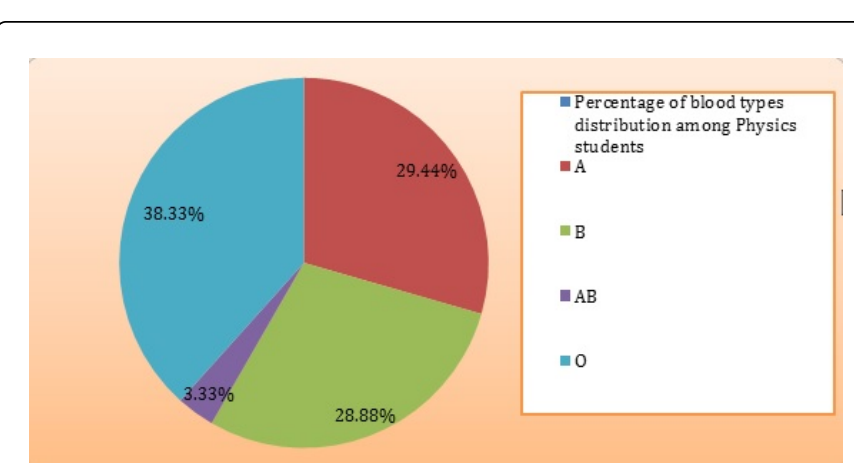

Figure 5: Percentage of blood type distribution among physics students of Dilla University

\section{Distribution of Rh-blood group based on sex among Physics students at Dilla University}

Amhara state, students had the Rh-positive blood types were $78.37 \%$ and $12.16 \%$ males and females respectively while Rh-negative blood types were $8.11 \%$ and $1.35 \%$ males and females respectively. Whereas, SNNP, students had the Rh-positive blood types were $66.66 \%$ and $2.56 \%$ males and females respectively while Rh-negative blood types were $25.64 \%$ and $5.13 \%$ males and females respectively (Table 2). Patel [20] had reported that looking at the rhesus grouping, on male sex, $21.07 \%$ were $\mathrm{Rh}$ positive A blood type and remaining $0.84 \%$ were $\mathrm{Rh}$ negative A blood type.

\begin{tabular}{|l|l|l|l|l|}
\hline $\begin{array}{l}\text { Ethnic } \\
\text { Groups }\end{array}$ & Sex & Rh-Positive & Rh-Negative & Total \\
\hline Amhara & Male & $\begin{array}{l}58(78.37 \%) \\
9(12.16 \%)\end{array}$ & $\begin{array}{l}6(8.11 \%) \\
1(1.35 \%)\end{array}$ & $\begin{array}{l}64(88.49 \%) \\
10(13.51 \%)\end{array}$ \\
\hline FNNP & Male & $26(66.66 \%)$ & $1(2.56 \%)$ & $27(69.23 \%)$ \\
& Female & $10(25.64 \%)$ & $2(5.13 \%)$ & $12(30.77 \%)$ \\
\hline Oromia & Male & $35(67.31 \%)$ & $2(3.85 \%)$ & $37(71.15 \%)$ \\
$13(25.00 \%)$ & $2(3.85 \%)$ & $15(28.85 \%)$ \\
\hline Gambela & Memale & $8(80.00 \%)$ & $1(10.00 \%)$ & $9(90.00 \%)$ \\
$1(10.00 \%)$ & - & $1(10.00 \%)$ \\
\hline Tigray & Memale & $5(100.00 \%$ & - & $5(100.00 \%)$ \\
\hline Total & Female & - & - & - \\
\hline
\end{tabular}

Table 2: Rh blood group distribution among ethnic groups of 180 Physics students of Dilla University, Ethiopia

Oromia state, students had the Rh-positive blood types were $67.31 \%$ and $3.85 \%$ males and females respectively while Rh-negative blood types were $25.64 \%$ and $3.85 \%$ males and females respectively. On the other hand, Tigray ethnic groups of students had the Rh-positive blood types were $80.00 \%$ and $10.00 \%$ males and females respectively while Rh-negative blood types were $10.00 \%$ and $0.00 \%$ males and females respectively. And also, Gambela Peoples ethnic groups of students had the Rh-positive blood types were $100.00 \%$ and $0 \%$ males and females respectively while $\mathrm{Rh}$-negative blood types were $0.00 \%$ and $0.00 \%$ males and females respectively (Table 2). Patel [20] had reported that looking at the rhesus grouping, on male sex, $37.70 \%$ were $\mathrm{Rh}$ positive $\mathrm{B}$ blood type and remaining $1.55 \%$ were Rh-negative B blood type.

\section{Distribution of Rh-blood group among Physics students at Dilla University}

The highest Rh-blood types were 91.66\% Rh-positive blood types followed by $8.34 \% \mathrm{Rh}$-negative blood types (Figure 6). According to the Fareed [21] study on population, Khan with highest $\mathrm{Rh}(\mathrm{D})$ positive (96.03\%) with lowest $\mathrm{Rh}(\mathrm{D})$ negative (3.97\%) whereas Syed with lowest $\mathrm{Rh}(\mathrm{D})$ positive (87.86\%) and highest $\mathrm{Rh}(\mathrm{D})$ negative $(12.14 \%)$ among six populations. The $\mathrm{Rh}(\mathrm{D})$ negative frequency shows decreasing order: Syed $>$ Mir $>$ Malik $>$ Mughal $>$ Gujjar and Bakarwal $>$ Khan. Moreover, this study further confirmed that Rh-positive has the highest percentage frequency while Rh-negative has the lowest percentage frequency as observed in previous studies among different ethnic groups [16-18]. Patel [20] had reported that looking at the rhesus grouping, on females sex, $35.42 \%$ were Rh positive B blood type and remaining $2.91 \%$ were $\mathrm{Rh}$ negative B blood type.

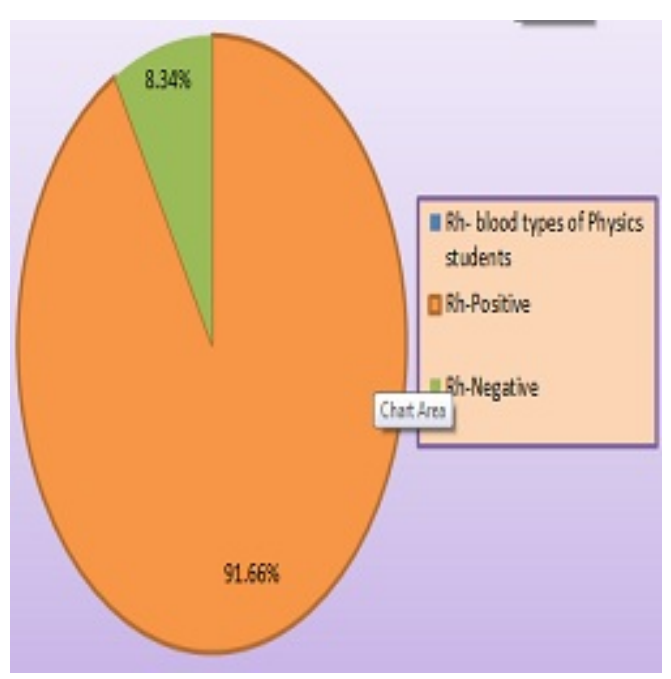

Figure 6: Rh-blood types distribution among Physics students in Dilla University

\section{Distribution of Rh-blood group in each sex of Physics students at Dilla University}

The $22.97 \%, 20.27 \%, 2.70 \%, 32.43 \%$ and $4.05 \%, 5.41 \%, 0 \%, 2.7 \%$ of the Physics students males and females were Rh-positive blood group $\mathrm{A}+, \mathrm{B}+, \mathrm{AB}+$ and $\mathrm{O}+$ respectively while $\mathrm{Rh}$ negative males and females students were $1.35 \%, 4.05 \%, 0 \%, 2.70 \%$ and $1.35 \% 0 \%, 0 \%, 0 \%, \mathrm{~A}-$, B-, $\mathrm{AB}$ - and $\mathrm{O}-$ had this blood group, the students which came from Amhara state respectively (Table 3). Whereas, the $20.51 \%, 23.08 \%$, $2.56 \%, 20.51 \%$ and $5.13 \%, 7.70 \%, 0 \%, 12.82 \%$ of the Physics students males and females were $\mathrm{Rh}$-positive blood group $\mathrm{A}+, \mathrm{B}+, \mathrm{AB}+$ and $\mathrm{O}+$ respectively while $\mathrm{Rh}$ negative males and females students were $0 \%$, $2.56 \%, 0 \%, 0 \%$ and $0 \%, 2.56 \%, 0 \%, 2.56 \%, \mathrm{~A}-, \mathrm{B}-, \mathrm{AB}-$ and O- had this blood group, the students which came from SNNP respectively. On the other hand, the $23.08 \%, 11.54 \%, 1.92 \%, 30.77 \%$ and $9.62 \%, 7.70 \%$, $1.92 \%, 5.77 \%$ of the Physics students males and females were Rh- 
positive blood group $\mathrm{A}+, \mathrm{B}+, \mathrm{AB}+$ and $\mathrm{O}+$ respectively while $\mathrm{Rh}$ negative males and females students were $0 \%, 1.92 \%, 0 \%, 1.92 \%$ and $0 \%, 1.92 \%, 1.92 \%, 0 \%, \mathrm{~A}-, \mathrm{B}-, \mathrm{AB}-$ and $\mathrm{O}-$ had this blood group, the students which came from Oromia state respectively. According to the study of Hussain [19] had reported, Out of the 724 subjects tested 613 (84.67\%) subjects were $\mathrm{Rh}+\mathrm{ve}$ and 111 (15.33\%) subjects were Rh-ve. The highest of Rh-ve individuals is found in Sheikh (19.09\%), while in other populations it ranges from 11-19\%. Patel et al. had reported that looking at the rhesus grouping, on male's sex, $28.78 \%$ were $\mathrm{Rh}$ positive O blood type and remaining $1.98 \%$ was $\mathrm{Rh}$ negative O blood type.

\begin{tabular}{|c|c|c|c|c|c|c|}
\hline $\begin{array}{l}\text { Ethnic } \\
\text { Groups }\end{array}$ & $\begin{array}{l}\text { Rh- } \\
\text { blood } \\
\text { groups }\end{array}$ & A & B & $A B$ & 0 & Total \\
\hline Amhara & $\begin{array}{l}\text { Male }^{+} \\
\text {Female } \\
+ \\
\text { Male }^{-} \\
\text {Female }^{-}\end{array}$ & $\begin{array}{l}17 \\
(22.97 \%) \\
3(4.05 \%) \\
1(1.35 \%) \\
1(1.35 \%)\end{array}$ & $\begin{array}{l}15 \quad(20 . \\
27 \%) \\
4(5.41 \%) \\
3(4.05 \%) \\
-\end{array}$ & $\begin{array}{l}2 \\
(2.70 \%) \\
- \\
- \\
-\end{array}$ & $\begin{array}{l}24 \\
(32.43 \%) \\
2(2.70 \%) \\
2(2.70 \%) \\
-\end{array}$ & $\begin{array}{l}58 \\
(78.38 \%) \\
9(12.16 \%) \\
6(8.11 \%) \\
1(1.35 \%)\end{array}$ \\
\hline SNNP & $\begin{array}{l}\text { Male }^{+} \\
\text {Female } \\
+ \\
\text { Male }^{-} \\
\text {Female }^{-}\end{array}$ & $\begin{array}{l}8 \\
(20.51 \%) \\
2(5.13 \%) \\
- \\
-\end{array}$ & $\begin{array}{l}9 \\
(23.08 \%) \\
3(7.70 \%) \\
1(2.56 \%) \\
1(2.56 \%)\end{array}$ & $\begin{array}{l}1 \\
(2.56 \%) \\
- \\
- \\
-\end{array}$ & $\begin{array}{l}8 \\
(20.51 \%) \\
5 \\
(12.82 \%) \\
- \\
1(2.56 \%)\end{array}$ & $\begin{array}{l}26 \\
(66.67 \%) \\
10 \\
(25.64 \%) \\
1(2.56 \%) \\
2(5.13 \%)\end{array}$ \\
\hline Oromia & $\begin{array}{l}\text { Male }^{+} \\
\text {Female } \\
+ \\
\text { Male }^{-} \\
\text {Female }^{-}\end{array}$ & $\begin{array}{l}12 \\
(23.08 \%) \\
5(9.62 \%) \\
- \\
-\end{array}$ & $\begin{array}{l}6 \\
(11.54 \%) \\
4(7.70 \%) \\
1(1.92 \%) \\
1(1.92 \%)\end{array}$ & $\begin{array}{l}1 \\
(1.92 \%) \\
1 \\
(1.92 \%) \\
- \\
1 \\
(1.92 \%)\end{array}$ & \begin{tabular}{|l|}
16 \\
$(30.77 \%)$ \\
$3(5.77 \%)$ \\
$1(1.92 \%)$ \\
-
\end{tabular} & $\begin{array}{l}35 \\
(67.31 \%) \\
13 \\
(25.00 \%) \\
2(3.85 \%) \\
2(3.84 \%)\end{array}$ \\
\hline $\begin{array}{l}\text { Gambel } \\
\text { a } \\
\text { Peoples }\end{array}$ & $\begin{array}{l}\text { Male }^{+} \\
\text {Female } \\
+ \\
\text { Male }^{-} \\
\text {Female }^{-}\end{array}$ & $\begin{array}{l}1 \\
(20.00 \%) \\
- \\
- \\
-\end{array}$ & \begin{tabular}{|l|} 
\\
$(40.00 \%)$ \\
- \\
- \\
-
\end{tabular} & - & 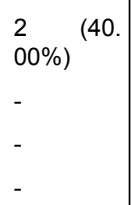 & $\begin{array}{l}5 \\
(100.00 \%) \\
- \\
- \\
-\end{array}$ \\
\hline Tigray & $\begin{array}{l}\text { Male }^{+} \\
\text {Female } \\
+ \\
\text { Male }^{-} \\
\text {Female }^{-}\end{array}$ & $\begin{array}{l}3 \\
(30.00 \%) \\
- \\
- \\
-\end{array}$ & $\begin{array}{l}2 \\
(20.00 \%) \\
- \\
- \\
-\end{array}$ & - & $\begin{array}{l}3 \\
(30.00 \%) \\
1 \\
(10.00 \%) \\
1 \\
(10.00 \%) \\
-\end{array}$ & $\begin{array}{l}8(80.00 \%) \\
1(10.00 \%) \\
1(10.00 \%) \\
-\end{array}$ \\
\hline
\end{tabular}

Table 3: Rh blood group distribution based on sex among ethnic groups of 180 Physics students of Dilla University, Ethiopia

The following are the blood samples of various blood groups taken and mixed with Anti-A, Anti-B and Anti-D (Anti-Rho D) Monoclonal and observed by naked eye and under the microscope either form clumping or not.

\section{A Positive group}

Figure 7A-7C shows the A Positive blood group sample on adding Antigen-A, Antigen-B and Antigen-D respectively. When Antibody A, Antibody B and Antibody D was added on the positive A blood type, the blood sample on slide A and C was form aggregates (agglutinate) but the blood sample found on slide B remain fluid (No aggregates).
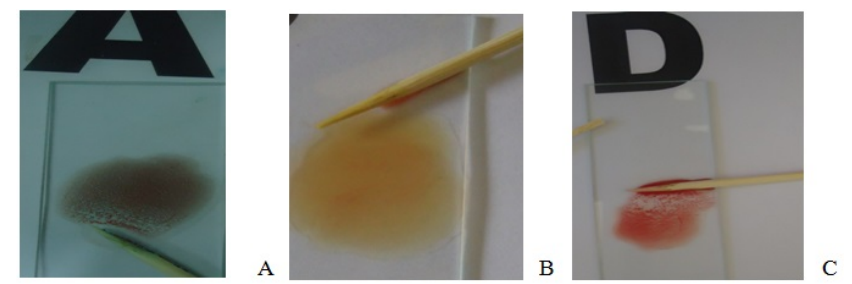

Figure 7: A Positive blood group samples

\section{A Negative group}

Figure $8 \mathrm{~A}-8 \mathrm{C}$ shows the A Negative blood group sample on adding Antigen-A, Antigen-B and Antigen-D respectively. When Antibody A, Antibody B and Antibody D was added on the positive A blood type, the blood sample on slide A was form clump (agglutinates) but the two blood sample found on slide B and C remain fluid (No clump).
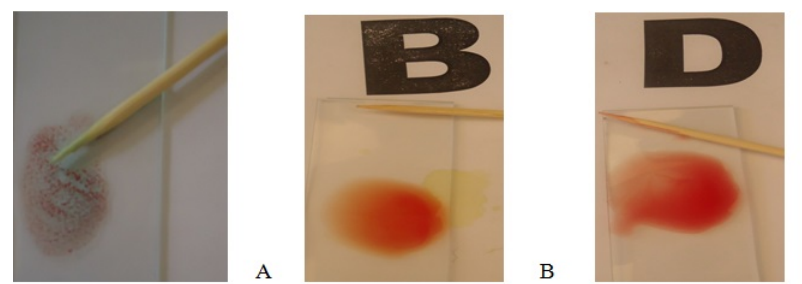

C

Figure 8: A Negative blood group sample

\section{B Positive group}

Figure 9A-9C shows the B Positive blood group sample on adding Antigen-A, Antigen-B and Antigen-D respectively. When Antibody A, Antibody B and Antibody D was added on the positive B blood type, the blood sample on slide $\mathrm{B}$ and $\mathrm{C}$ was form aggregates (agglutinates) but the blood sample found on slide A remain fluid (No aggregates).
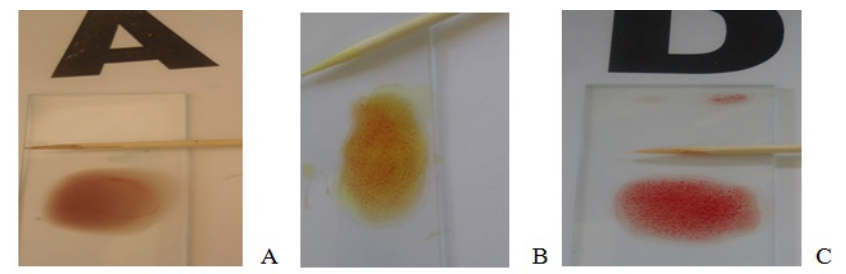

Figure 9: B Positive blood group sample

\section{B Negative group}

Figure 10A-10C shows the B Negative blood group sample on adding Antigen-A, Antigen- $B$ and Antigen-D respectively. When Antibody A, Antibody B and Antibody D was added on the positive B blood type, the blood sample only on slide B was form aggregates 
(agglutinates) but the two blood sample found on slide $\mathrm{A}$ and $\mathrm{C}$ remain fluid (No aggregates).
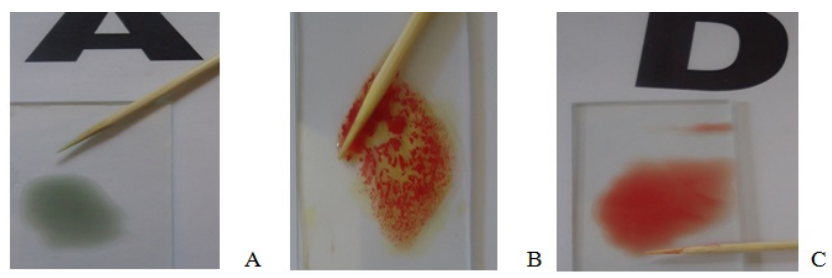

Figure 10: B Negative blood group sample

\section{AB Positive group}

Figure 11A-11C shows the $\mathrm{AB}$ Positive blood group sample on adding Antigen- $A$, Antigen- $B$ and Antigen-D respectively. When Antibody A, Antibody B and Antibody D was added on the positive AB blood type, all blood sample found on slide A, B and C was form aggregates (agglutinates).
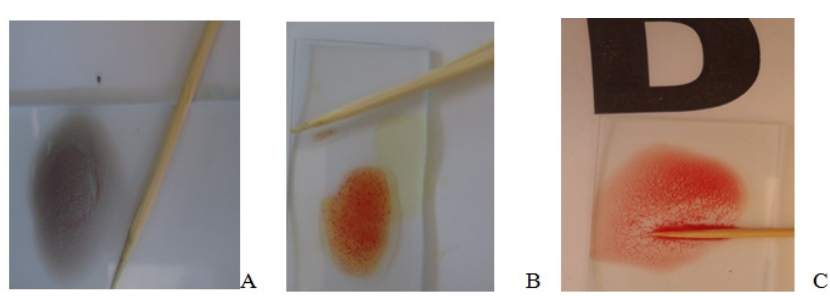

Figure 11: AB Positive blood group sample

\section{AB Negative group}

Figure $12 \mathrm{~A}-12 \mathrm{C}$ shows the $\mathrm{AB}$ Negative blood group sample on adding Antigen- $A$, Antigen- $B$ and Antigen-D respectively. When Antibody A, Antibody B and Antibody D was added on the negative $\mathrm{AB}$ blood type, the blood sample on slide $\mathrm{A}$ and $\mathrm{B}$ was form aggregates (agglutinates) but the blood sample found on slide $\mathrm{C}$ remain fluid (No aggregates).
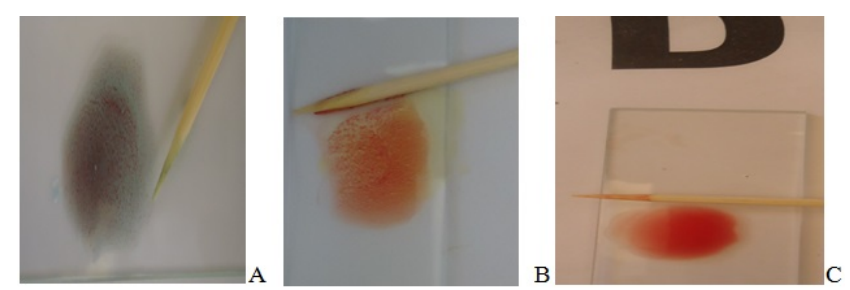

Figure 12: AB Negative blood group sample

\section{O Positive group}

Figure 13A-13C shows the $\mathrm{O}$ Positive blood group sample on adding Antigen-A, Antigen- $B$ and Antigen-D respectively. When Antibody A, Antibody B and Antibody D was added on the positive $\mathrm{O}$ blood type, the blood sample found only on slide $\mathrm{C}$ was form aggregates (agglutinates) but the two blood sample found on slide A and $\mathrm{B}$ remain fluid (No aggregates).
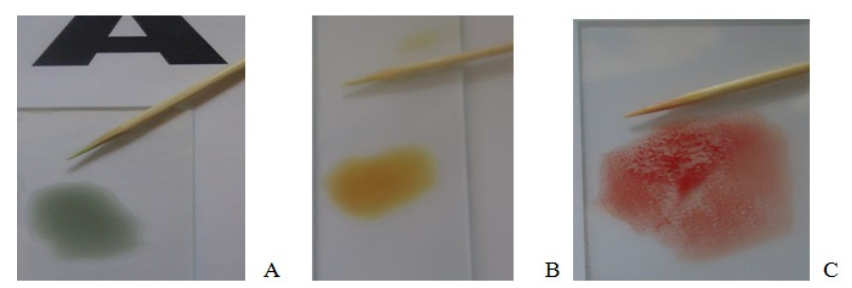

Figure 13: O Positive blood group sample

\section{O Negative group}

Figure 14A-14C shows the O Negative blood group sample on adding Antigen-A, Antigen-B and Antigen-D respectively. When Antibody A, Antibody B and Antibody D was added on the negative $\mathrm{O}$ blood type, all blood sample found on slide A, B and C was remain fluid (No aggregates).



Figure 14: O Negative blood group sample

\section{Conclusion}

The study revealed that the blood group of these five different ethnic group have different numbers of blood types that means the numbers blood type $\mathrm{A}$, blood type $\mathrm{B}$, blood type $\mathrm{AB}$, and blood type $\mathrm{O}$ are various. Therefore, $\mathrm{ABO}$ blood type and $\mathrm{Rh}$-blood groups varies among each ethnic group.

\section{Acknowledgements}

I am grateful thanks to Dilla University, College of Natural and Computational sciences, Department of Biology who are giving these facilities to conduct this study. I extend also my thanks to Physics undergraduate students of Dilla University who are voluntary to give their blood as a sample to determination their blood type and group and finally to generate this great important data.

\section{References}

1. http://www.moh.gov.et/

2. http://ibgrl.blood.co.uk/isbt

3. Sidhu S, Sidhu LS (1980) ABO blood group frequencies among the Sansis of Punjab. Coll Anthropol 4: 55-58.

4. Daniels G (2002) Human Blood Groups. (2ndedn.) Blackwell Science.

5. Estridge BH, Reynolds AP, Walters NJ (2000) Basic Medical Laboratory Techniques, (4thedn.) Thomson Learning. 
Citation: Atire FA (2015) Analysis of the Blood Type and Group among Undergraduate Physics Students of Dilla University, Ethiopia. Hereditary

6. Worlledge S, Ogiemudia SE, Thomas CO, Ikoku BN, Luzzatto L (1974) Blood group antigens and antibodies in Nigeria. Ann Trop Med Parasitol 68: 249-264.

7. Seeley RR, Stephens TD, Tate P (1998) Anatomy and Physiology (4thedn.) The McGraw Hill Companies, USA.

8. Landsteiner K, Weiner AS (1940) An agglutinable factor in human blood recognized by immune sera for rhesus blood. Proc Soc Exp Biol Med 43: 223-224.

9. Pramanik T, Pramanik S (2000) Distribution of ABO and Rh blood groups in Nepalese medical students: a report. East Mediterr Health J 6: 156-158.

10. Adeyemo OA, Soboyejo OB (2006) Frequency distribution of ABO, RH blood groups and blood genotypes among the cell biology and genetics students of University of Lagos, Nigeria. Afr J Biotechnol 5: 2062-2065.

11. Mwangi J (1999) Blood group distribution in an urban population of patient targeted blood donors. East Afr Med J 76: 615-618.

12. Omotade OO, Adeyemo AA, Kayode CM, Falade SL, Ikpeme S (1999) Gene frequencies of $\mathrm{ABO}$ and $\mathrm{Rh}$ (D) blood group alleles in a healthy infant population in Ibadan, Nigeria. West Afr J Med 18: 294-297.

13. Enosolease ME, Bazuaye GN (2008) Distribution of $\mathrm{ABO}$ and Rh-D blood groups in the Benin area of Niger-Delta: Implication for regiona blood transfusion. Asian J Transfus Sci 2: 3-5.
14. Dacie JV, Lewis SM (2001) Practical Haematology. (9thedn.) Churchill Livingstone, Harcourt Publishers Limited, London.

15. Pramanik T, Pramanik S (2000) Distribution of ABO and Rh blood groups in Nepalese medical students: a report. East Mediterr Health J 6: 156-158.

16. Nwauche CA, Ejele OA (2004) ABO and rhesus antigens in a cosmopolitan Nigeria population. Niger J Med 13: 263-266.

17. Kulkarni AG, Peter B, Ibazebo R, Dash B, Fleming AF (1985) The ABO and Rhesus groups in the north of Nigeria. Ann Trop Med Parasitol 79: 83-88.

18. Falusi AG, Ademowo OG, Latunji CA, Okeke AC, Olatunji PO, et al. (2000) Distribution of ABO and RH genes in Nigeria. Afr J Med Med Sci 29: 23-26.

19. Hussain R, Fareed M, Shah A, Afzal M (2013) Prevalence and gene frequencies of $\mathrm{A} 1 \mathrm{~A} 2 \mathrm{BO}$ and $\mathrm{Rh}(\mathrm{D})$ blood group alleles among some Muslim populations of North India. Egypt J Med Hum Genet 14: 69-76.

20. Patel PA, Patel SP, Shah JV, Oza HV (2012) Frequency and distribution of blood groups in blood donors in western ahmedabad a hospital based study. National Journal of Medical Research 2: 202-206.

21. Fareed M, Hussain R, Shah A, Afzal M (2014) Aa, Aa, BO and Rh gene frequencies among six populations of Jammu and Kashmir, India. Transfus Apher Sci 50: 247-252. 